\title{
PRODUCTIVITY GAP BY GENDER AMONG RICE FARMERS IN NORTH-CENTRAL NIGERIA
}

\author{
Sadiq, M.S ${ }^{1 *}$, Singh, I.P2, Ahmad, M.MP \\ ${ }^{1}$ Department of Agricultural Economics and Extension, FUD, Dutse, Nigeria \\ ${ }^{2}$ Department of Agricultural Economics, SKRAU, Bikaner, India \\ ${ }^{3}$ Department of Agricultural Economics, BUK, Kano, Nigeria \\ *corresponding author: sadiqsanusi30@gmail.com
}

\begin{abstract}
The present research used a field survey data of 2020 rice cropping season to determine yield gap by gender among rice farmers in North-Central Nigeria. A total of 376 farmers were drawn from a sampling frame through a multi-stage sampling technique and a structured questionnaire coupled with interview schedule was used for information elicitation. Both descriptive and inferential statistics were used for data analysis. The empirical evidences showed that most of the farmers have negative attitudes towards risk and this owes to poor resource capital base, thus hinders cultivation of economic holdings. Besides, women farmers were more averse to risk than the men farmers which owes largely to gender discrimination and stereotype induced by culture and religion, thus hindered their access to and control over productive resources. Furthermore, neither gender nor risk attitudinal differentials have impact on the average yield of the farmers. However, it was established that yield gap was largely due to gender and risk attitudinal discriminations. Therefore, the study enjoins the farmers, especially the women folk to harness social capital viz. participation in co-operative association- pecuniary advantages, thus enable them to have access to and control over productive resources. In addition, the policymakers are advised to create an enabling agricultural environment for the women folk viz. gender budget mainstreaming, thus tackling women farmers' susceptibility to the vicious cycle of poverty.
\end{abstract}

Keywords: Gender, Yield, Gap, Rice, Farmers, Nigeria

http://dx.doi.org/10.21776/ub.agrise.2021.021.2.7

Received 28 January 2021

Accepted 29 April 2021

Available online 30April 2021

\section{INTRODUCTION}

Smallholder farmers are the heroes who provide a great deal of food in the world, but they are also the poorest and most malnourished. Globally, 2.5 billion smallholder farmers make daily decisions to protect their livelihoods and nourish their communities (Digital Green, no date). Every day, these farmers receive a staggering amount of information from government extension officers, private agribusinesses, and NGOs. Farmers are given information and services that they have not requested and cannot use; and are forced to make obscure decisions due to poor coordination between these actors. The gap between what is needed and what is offered continues to widen as climate change increasingly threatens development, and as supply chains are disrupted by crises like COVID-19.

In sub-Saharan Africa, growth in agricultural productivity has been described as a key driver of poverty reduction and increased food security (Ligon and Sadoulet, 2008; Sepahvand, 2019). These goals are formalized by the United Nations Agenda 2030 as the Sustainable Development Goal (SDG) 1 (No Poverty) and SDG 2 (Zero Hunger). When women farmers have the same access to productive resources as men, they can increase yields by 20 to 30 percent, according to Sepahvand (2019). In developing countries, this could potentially increase overall agricultural output by 2.5 to 4 percent and lift 100 to 150 million people

CITATION: Sadiq, M., S., Singh, I., P., Ahmad, M., M., (2021). Productivity Gap by Gender Among Rice Farmers In NorthCentral Nigeria, Agricultural Socio-Economics Journal, $21(2), \quad 135-148 \quad$ DOI: http://dx.doi.org/10.21776/ub.agrise.2021.021.2.7 
out of hunger. Recent literature, however, argues that lower female productivity, or female farmers' inability to respond to economic incentives, is due to their inability to take higher risks. For example, in their study, Averett et al.(2018) found that in the higher payoff treatments, gender gap disappears when women show a greater willingness to take risk. However, empirical literature has shown that because of risk domains (Dohmen et al., 2011; 2012) and elicitation techniques, the presence and magnitude of gender differences in risk taking can change (Charness et al., 2013).

The quantity of essential inputs, such as fertilizers, seeds and labor, in sub-Saharan Africa can lead to gender differences in agricultural productivity, even if female and male farmers have the same underlying agricultural production function, although the same technique is used for similar crops (Amber et al., 2014). In addition, the quality of the critical inputs used in agricultural production may vary between male and female farmers as well. This could be due to legal standards that restrict the rights of women to have access to high-quality land or soil (Cotula, 2006; Sepahvand, 2019). The belief, however, that female and male farmers in agriculture have the same underlying output function does not always hold. Most likely, this is because crop choices vary by gender. In explaining gender differences in agricultural productivity, cultural norms play an important role as they affect crop choices. Another major reason for variations in crop choices by gender is credit limitation. This credit limitation can cause the female farmers' output frontier to persist under that of males, indicating lower female productivity.

Succinctly, agriculture is a risky activity: farmers work in risky and unpredictable circumstances in developing countries (Di Falco and Chavas, 2009; Sepahvand, 2019). The risk attitudes of farmers are an important factor which affects their decisions on farm production, investment and management. Higher-payoff practices and investments will be avoided by farmers less likely to take risk (Alderman, 2008). Farm households are vulnerable to climate variability and demand fluctuations. These shocks could place farmers in a position to have nothing or to lose what they have. Agricultural risk-taking is also influenced by the geographical isolation of development regions and restricted access to credit or insurance coverage (Sepahvand, 2019). Wealth is also correlated with a greater willingness to take chances in agriculture, as wealthier farm households engage in more risky decisions and receive higher returns as a result (Sepahvand, 2019).

The main objective of this study is to enhance understanding of the relationship between risk-taking and gender-based productivity in agriculture. In order to identify potential policy recommendations to minimize gender disparities in agricultural productivity, understanding how these factors affect productivity differences is fundamental. These policies are of particular importance in promoting and supporting the SDGs with a view to achieving sustainable development with reduced hunger, higher food security and higher agricultural productivity, improved livelihoods and equality between women and men. This will provide valuable feedback for policy initiatives to mitigate the gender gap in agricultural productivity. This research will contribute to/add to the literature by specifically examining the risk taken by female farmers and its effects on agricultural productivity using a broad, representative sample of farmers.

Therefore, this research attempted to determine rice productivity gap by gender among rice farmers in North-Central Nigeria. While the specific objectives were to determine the risk attitudes of the farmers vis-à-vis gender; determine the factors affecting rice productivity among the farmers; determine the impact of gender and risk attitude differentials on farmers' yield; and, determine the effect of gender and risk behaviour discriminations on farmers' yield.

\section{RESEARCH METHODOLOGY}

The North-Central region is geographically located in the middle belt of Nigeria and consists of six states viz. Benue, Nasarawa, Niger, Plateau, Kogi and Kwara; and a Federal unity territory called Abuja. The region spanned from the west to around the serenity of the confluence of two major riversRiver Niger and River Benue. The geographical coordinates of the region are latitude $10^{\circ} 20^{\prime}$ and longitude $7^{\circ} 45^{\prime}$; and its vegetation cover is largely guinea savannah alongside mountainous and tropical 
vegetations. The mean cumulative annual and monthly rainfall of the region are 1247.52 \pm 166.68 $\mathrm{mm}$ and $103.96 \mathrm{~mm}$, respectively; while the annual mean temperatures hovered around minimum and maximum values of $22.55 \pm 0.42^{\circ} \mathrm{C}$ and $33.54 \pm$ $0.23^{\circ} \mathrm{C}$. The mean is slightly above 50 percent for the relative humidity and varied between the small range of 50.08 and 52.75 percent. The distribution of monthly rainfall ranges from May to October, with a uni-modal peak in August (274.23mm) (Olayemi et al., 2014). The months of January and February are completely dry season (no rainfall) while the months of April and November witnessed little spring, thus referenced as pre and post-rainy season transition periods respectively. The inhabitants of the region majorly engaged in arable crop production alongside tree cropping, fishing, hunting, artisanal, civil service and Ayurvedic medicines. In achieving a representative sampling size, a multi-stage sampling technique was adopted. With the exception of Benue state, all the state units and the Federal unity territory are suitable for cultivation of rice. Thus, three out of the seven units viz Niger and Kogi States; and FCT Abuja were conveniently selected. Given the preponderance of rice cultivation across the chosen units, two Local Government Areas (LGAs)/Municipal Area Councils (MAC) were randomly selected from each of the selected units using Microsoft inbuilt sampling analytical tool. Furthermore, using the same Microsoft sampling analytical tool, two villages were randomly selected from each of the chosen LGAs/MAC. Based on the sampling frame sourced from the States' Agricultural agencies and reconnaissance survey, a scale ratio of $18 \%$ was used to determine the representative sample size (Table 1). Thus, a total of 376 active rice farmers that made the sample size were drawn through simple random sampling technique. However, 16 out of the 376 questionnaires retrieved contained outliers, thus were eliminated. Therefore, a total of 360 valid questionnaires were subjected to the analysis. Using an easy cost route approach, a structured questionnaire complemented with interview schedule is the instrument used to elicit cross-sectional data of 2020 rice cropping seasons from the farmers. Objective I, II, III and IV were achieved using Sadiq-Singh-Makarfi risk safety approach; Average treatment effect; and, Oaxaca-Blinder decomposition models respectively.

Table 1: Sampling frame of rice farmers

\begin{tabular}{|l|c|c|c|c|}
\hline States & LGAs/MACs & Villages & Sample frame & Sample size \\
\hline FCT Abuja & Kwali & Dabi & 85 & 15 \\
\hline & & Gada-biu & 109 & 20 \\
\hline & Abaji & Yaba & 100 & 18 \\
\hline Kogi State & & Pandagi & 90 & 16 \\
\hline & Yagba West & Omi & 198 & 36 \\
\hline & & Ejiba & 220 & 40 \\
\hline & Kogi & Giryan & 250 & 45 \\
\hline Niger State & Borgu & Panda & 180 & 32 \\
\hline & & Swashi & 208 & 37 \\
\hline & Katcha & Saminaka & 170 & 31 \\
\hline Total & $\mathbf{6}$ & Kadcha & 238 & 43 \\
\hline
\end{tabular}

Source: States' Agricultural Agencies, 2020

Note: District unit is called Municipal Area Council (MAC) and Local Government area (LGA) in FCT Abuja and State respectively.

\section{Empirical model}

\section{Tobit regression model}

Given that censored regression model yield similar estimates with linear probability model (LPM); and
LPM not suitable for qualitative variables due to classical regression assumptions, the equation was fitted into censored regression model. Following 
Tobin (1958) as specified by Sadiq et al.(2020a \& b), the Tobit regression model is presented below: $Y_{i}^{*}=\alpha+X \beta+\varepsilon_{i}$

$Y_{i}^{*}=\alpha+X_{1} \beta_{1}+X_{2} \beta_{2}+X_{3} \beta_{3}+X_{4} \beta_{4}+X_{5} \beta_{5}+$ $\cdots .+X_{n} \beta_{n}+\varepsilon_{i}$

Where:

$\mathrm{Y}_{\mathrm{i}}{ }^{*}=$ Yield value for $\mathrm{i}^{\text {th }}$ farmer;

$\mathrm{X}_{1}=$ Age (years); $\mathrm{X}_{2}=$ Gender $($ male $=1$, female $=0$ ); $\mathrm{X}_{3}=$ Marital status (married $=1$, otherwise $=0$ ); $\mathrm{X}_{4}=$ Education (years); $\mathrm{X}_{5}=$ Household size (number); $\mathrm{X}_{6}$ $=$ Experience (year); $\mathrm{X}_{7}=$ Mode of land acquisition (inheritance $=1$, otherwise $=0$ ); $\mathrm{X}_{8}=$ Distance from house to farm (DHF) (kilometer); $\mathrm{X}_{9}=$ Distance from house to market (DHM)(kilometer); $\mathrm{X}_{10}=\mathrm{Co}-$ operative membership (yes $=1$, otherwise $=0$ ); $\beta_{0}=$ Intercept; $\beta_{1-n}=$ Vector of parameters to be estimated; and, $\varepsilon_{\mathrm{i}}=$ Chance.

\section{Sadiq-Singh-Makarfi risk safety approach model:}

Step 1:

Exploratory factor analysis: The exploratory factorprincipal component analysis was used to reduce the production variables- output and inputs to weight. The Kaiser Mayer Olkin (KMO) test of sampling adequacy attained a mediocre level with a value of 0.692, greater than the threshold value of 0.50 benchmarked by Kaiser (1974) to be suitable for analysis. This indicates that there is a common variable applicable to all the factors and the sample is adequate. Besides, the Bartlett's Sphericity test (BST) was significant at 1 percent, indicating that the rotated variables are not identity matrix. The Varimax rotated matrix generated four factors based on Eigen-value greater than unity and these factors accounted for $69.72 \%$ of the total variation (Table 2).

Table 2: Varimax rotation factor of production components

\begin{tabular}{|l|c|c|c|c|c|c|}
\hline Items & EV & \% of Var. & Factor 1 & Factor 2 & Factor 3 & Factor 4 \\
\hline Output & 2.318 & 28.975 & 0.631 & & & \\
\hline Labour & 1.183 & 14.793 & & 0.704 & & 0.966 \\
\hline Fertilizer & 1.055 & 13.188 & & & & \\
\hline Seed & 1.021 & 12.768 & 0.653 & & & \\
\hline Herbicides & & & 0.799 & & & \\
\hline Pesticides & & & & & & \\
\hline Capital Dep. & & & 0.753 & & & \\
\hline Farm size & & & & 0.801 & & \\
\hline Total & \multicolumn{7}{|l|}{$\mathbf{6 9 . 7 2 4}$} & & & & \\
\hline KMO & \multicolumn{7}{|l}{$\mathbf{0 . 6 9 2}$} \\
\hline BST
\end{tabular}

Source: Field survey, 2020

Note: value in parenthesis is probability value; $\mathrm{EV}=$ Eigen value; Var. = Variance

Step 2: To obtain the risk index, the production variables were normalized- Z-score normalization and then multiplied by their respective weight generated from the Varimax rotation. Presented below is the risk index model:

\section{Normalization index}

$I_{i}=\frac{P_{i}-\bar{P}}{S D}$
Where $I_{i}$ is the normalized value of the $\mathrm{i}^{\text {th }}$ farmer for a production component indicator; $P_{i}$ is the actual production component value of $i^{\text {th }}$ farmer; $\bar{P}$ is the average value of the production component; and, SD is the standard deviation value of the production component.

$R_{i}=\frac{\sum_{k=1}^{n} W_{k} I_{k}}{\sum_{k=1}^{n} W_{k}}$ 
This can further be expressed as:

$R_{i}=\frac{W_{Y} I_{Y}+W_{X 1} I_{X 1}+W_{X 2} I_{X 2}+W_{X 3} I_{X 3}+W_{X 4} I_{X 4}+W_{X 5} I_{X 5}+W_{X 6} I_{X 6}+W_{X 7} I_{X 7}+W_{X 8} I_{X 8}}{W_{Y}+W_{X 1}+W_{X 2}+W_{X 3}+W_{X 4}+W_{X 5}+W_{X 6}+W_{X 7}+W_{X 8}}$

Where, $R_{i}=$ risk index; $\mathrm{W}=$ weight; $\mathrm{Y}=$ output $(\mathrm{kg})$; X1-X8 are human labour, inorganic fertilizer, seeds, herbicides, pesticides, depreciation on capital items and farm size respectively.

\section{Average Treatment Effect (ATE)}

ATE: It show the average difference in outcome between units assigned to the treatment and units assigned to the placebo (control). Following Lokshin and Sajaia (2011); Wang et al. (2017); Sadiq et al. $(2020 \mathrm{a} \& \mathrm{~b})$ the equation is given below:

Yield index of male farmers/ risk non-averse is given by:

$$
E\left(y_{1 i} \mid I=1 ; X\right) \ldots \ldots \ldots(6)
$$

Yield index of female farmers/ risk non-averse is given by:

$$
E\left(y_{2 i} \mid I=0 ; X\right) \ldots(7)
$$

Yield index of male farmers/risk non-averse if there is no gender/risk difference is denoted by:

$$
E\left(y_{2 i} \mid I=1 ; X\right) \ldots \ldots(8)
$$

Yield index of female farmers/ risk non-averse if there is gender/risk difference:

$$
E\left(y_{1 i} \mid I=0 ; X\right)
$$

Where:

$$
\begin{aligned}
& E(.) \quad=\text { Expectation operator } \\
& y_{1 i}=\text { yield index of male farmers/ risk non- } \\
& \text { averter farmers (dependent variable) } \\
& y_{2 i}=\text { yield index of female farmers/ risk averter } \\
& \text { farmers (dependent variable) } \\
& I=\text { Dummy variable }(1=\text { male/risk non- } \\
& \text { averter, } 0=\text { female/ risk averter) } \\
& \mathrm{ATT}=E\left(y_{1 i} \mid I=1 ; X\right)-E\left(y_{2 i} \mid I=\right. \\
& 1 ; X) \ldots \\
& A T U=E\left(y_{1 i} \mid I=1 ; X\right)-E\left(y_{2 i} \mid I=\right. \\
& 1 ; X)
\end{aligned}
$$

$$
\begin{gathered}
\text { Average Treatment effect on Treated } \\
=\text { ATT } \\
\begin{array}{c}
\text { Average Treatment effect on Untreated } \\
=\text { ATU }
\end{array}
\end{gathered}
$$

Equations (10) and (11) were further simplified as:

$$
\begin{aligned}
& \mathrm{ATT}=\frac{1}{N_{1}} \sum_{i=1}^{N_{1}}\left[p\left(y_{1 i} \mid I=1 ; X\right)-p\left(y_{2 i} \mid I=\right.\right. \\
& 1 ; X)] \ldots \\
& \mathrm{ATU}=\frac{1}{N_{2}} \sum_{i=1}^{N^{2}}\left[p\left(y_{2 i} \mid I=0 ; X\right)-p\left(y_{1 i} \mid I=\right.\right. \\
& 0 ; X)]
\end{aligned}
$$

Where, $N_{1}$ and $N_{2}$ are number of male farmers/ risk non-averter farmers and female farmers/risk averter farmers respectively, and $p=$ probability.

\section{Oaxaca-Blinder Decomposition model}

Using the standard Oaxaca-Blinder procedure (Oaxaca 1973; Blinder 1973) the extent to which the risk gap between the male and female farmers/ risk non-averter and averter farmers can be explained by differences in observed human capital characteristics (Marwa, 2014; Revathy et al., 2020; Sadiq et al., 2020a\&b).

$$
\begin{aligned}
& \ln \bar{Y}_{W / R N}=\beta_{0}+\beta_{i} \sum_{i=1}^{i} X_{i}+\varepsilon_{i} \ldots \\
& \ln \bar{Y}_{M / R P}=\beta_{0}+\beta_{i} \sum_{i=1}^{i} X_{i}+\varepsilon_{i} \ldots
\end{aligned}
$$

Where,

$\bar{Y}_{W / R N}=$ average yield of women folk/ risk negative (risk averse) attitude farmers;

$\bar{Y}_{M / R P}=$ average yield of men folk/ risk positive (risk non-averse) attitude farmers; $X_{i-n}=$ explanatory variables;

$\beta_{0}=$ intercept

$\beta_{i-n}=$ parameter estimates; and, $\varepsilon_{i}=$ stochastic term.

Following Revathy et al.(2020); Sadiq et al. (2020a\&b), equations 14 and 15 of the OaxacaBlinder decomposition can be explained as follow: 


$$
\begin{aligned}
\left(\ln \bar{Y}_{F}-\ln \bar{Y}_{M}\right)= & \left(\beta_{F 0}-\beta_{M 0}\right)+\left[\beta_{F 1}\left(\bar{X}_{F 1}-\bar{X}_{M 1}\right)+\beta_{F 2}\left(\bar{X}_{F 2}-\bar{X}_{M 2}\right)+\beta_{F 3}\left(\bar{X}_{F 3}-\bar{X}_{M 3}\right)+\beta_{F 4}\left(\bar{X}_{F 4}-\bar{X}_{M 4}\right)+\right. \\
& \left.\beta_{F n}\left(\bar{X}_{F n}-\bar{X}_{M n}\right)\right]+\left[\bar{X}_{M 1}\left(\beta_{F 1}-\beta_{M 1}\right)+\bar{X}_{M 2}\left(\beta_{F 2}-\beta_{M 2}\right)+\bar{X}_{M 3}\left(\beta_{F 3}-\beta_{M 3}\right)+\bar{X}_{M 4}\left(\beta_{F 4}-\right.\right. \\
& \left.\beta_{M 4}\right)+\bar{X}_{M n}\left(\beta_{F n}-\beta_{M n}\right)+\left(\varepsilon_{F}-\varepsilon_{M}\right) \ldots \ldots \ldots \ldots \ldots \ldots \ldots \ldots \ldots \ldots \ldots \ldots \ldots \ldots \ldots \ldots \ldots \ldots \ldots \ldots \ldots \ldots \ldots \ldots \ldots \ldots \ldots \ldots \ldots \ldots \ldots \ldots \ldots \ldots \ldots \ldots \ldots \ldots \ldots
\end{aligned}
$$

The yield gap is divided into two segments: one is the proportion attributable to differences in the endowments generating activities $\left(\bar{X}_{F}-\bar{X}_{M}\right)$ evaluated at the female group returns $\left(\beta_{F}\right)$. This is taken as a reflection of endowment differential and it's termed endowment/characteristics/explained effect. The second segment is attributable to the difference in the returns $\left(\beta_{F}-\beta_{M}\right)$ that the female and male groups get for the same endowment generating activities $\left(\bar{X}_{F}\right)$. This segment is often taken as a reflection of discrimination viz. gender/risk attitudes and its termed discrimination or unexplained effect.

\section{RESULTS AND DISCUSSION Farmers' Risk Behaviours}

Most of the farmers (61.1\%) have negative attitude (risk averter) towards risk and the possible reason is due to their poor capital resource base, thus cultivation of thinly uneconomic holdings with little or no capacity for balanced marketable surplus (Table 3). This category of farmers farm exclusively for home consumption, and if there is a surplus, though very rare, they will sell it in the market. Often these farmers are struggling with the basic survival of themselves and families. While they may be entrepreneurial in spirit, they usually lack the opportunity to produce as entrepreneurs because they are rarely in the position to commit their minds and bodies to entrepreneurship. Though, $34.7 \%$ of the farmers were risk neutral- produced partly for home consumption and market; while $4.2 \%$ were risk lover- innovators that exclusively produced for the market. In the risk-neutral category two sets of farmers exist- farm mostly for home consumption but with the intention of selling surplus in the market; and those that produced partly for home consumption and partly for market. The risk neutral category can be presumed to understand the value of farming for the market but often they are limited by access to finance and market information. For the former farmers, they have greater opportunities that allow them to produce just beyond survival, thus viewed as 'pre-entrepreneurial', requiring support to move into independent position. In true sense, at this level, they are not entrepreneurs neither are they truly market-oriented. Though the opportunities are limited, but by changing their resource mix and overcoming access and risk issues, opportunities can be expanded. While for the latter, they are on the path towards developing profit-driven rice farming business as they possessed the skills, but they cannot risk household food security without greater certainty of income from rice crop. The risk preference farmers are entrepreneurs that are mainly driven by profit, thus produced for the market.

The gender decomposition results showed the women farmers to be more risk averse (63.2\%) than their men counterparts $(60.6 \%)$ while on the other hand the men folk were more risk neutral $(34.9 \%)$ and risk lover (4.5\%) than the women folk (risk neutral: $33.8 \%$; risk preference: $2.9 \%$ ) (Table $3)$. On the average, most of the women and men farmers are risk averse and risk neutral respectively, as evidenced by their respective risk index that are 0.0618 and 0.0144 , respectively. The possible reason for this negative skewed risk averse of the women farmers may be attributed to the consequences of cultural and religious barriers-gender discrimination and gender stereotype, thus hindered women access and control over productive resources. Generally, it can be inferred that most of the farmers are not disposed to risk preference due to limited access to capital and market information despite that most of them have market-focus, thus government effort towards revising the chasm-achieving selfsufficiency in rice production in the region is likely to be a mirage. 
Table 3: Risk attitudes vis-à-vis gender and co-operative participation

\begin{tabular}{|l|l|l|l|}
\hline Risk attitude index & Overall & Men & Women \\
\hline Risk averse $(<0.00)$ & $220(61.1)$ & $177(60.6)$ & $43(63.2)$ \\
\hline Risk neutral $(0-0.99)$ & $125(34.7)$ & $102(34.9)$ & $23(33.8)$ \\
\hline Risk preference $(\geq 1.00)$ & $15(4.2)$ & $13(4.5)$ & $2(2.9)$ \\
\hline Total & $260(100)$ & $292(100)$ & $68(100)$ \\
\hline Mean & -0.02936 & 0.014409 & -0.061875 \\
\hline Minimum & -0.6932 & -0.6859 & -0.6932 \\
\hline Maximum & 2.5878 & 2.5878 & 1.5095 \\
\hline
\end{tabular}

Source: Authors' own computation, 2020

Note: value in ( ) is percentage; $\mathrm{CP}$ and $\mathrm{NCP}$ are co-operative participation and non-cooperative participation respectively.

\section{Determinants of Yield}

The significant of the $\mathrm{LR} \mathrm{Chi}^{2}$ at $1 \%$ probability level implies that the censored regression is best fit for the specified equation (Table 4). In addition, it implies that the estimated parameters are different from zero at $10 \%$ probability level. Besides, all the predictor variables were within the variance inflation factors (VIF) threshold of 10.00, thus indicating absence of orthogonality. The residual of the estimated model was normally skewed as evidenced by the non-significant of the $\mathrm{Chi}^{2}$ test statistic at $10 \%$ significance level. Thus, it can be inferred that the chosen model is reliable for prediction with certainty, efficiency and consistency.

Farmers' yield were influenced by marital status, household size, farming experience, distance from house to market and co-operative membership as indicated by their respective estimated coefficients that are within the acceptable margin of $10 \%$ probability level. The positive significance of marital status revealed how the quest to sustain family livelihood incentivized married farmers to engage in sustainable rice production, thus increase in their yield. In addition, access to twin capitalsocial and economic serves as impetus for married farmers' access to procure rice technologies, thus increase in their rice yield. The marginal and elasticity implications of being married would increase farmers yield by 0.24 and $2.77 \%$ respectively. The negative sign and significant of the household coefficient showed how labour drift to white collar jobs among the able-bodied household members plummeted farmers yield. In addition, high household expenditure viz. medics and food affected the farmers' poor income base-capital investment, thus plummeted yield due to farmers' weak wherewithal to adopt innovative rice technologies. Thus, the marginal and elasticity implications of a unit increase in a farmer's household size by one person will lead to a decrease in his/her yield by 0.53 and $3.15 \%$ respectively.

The positive sign and significant of the experience coefficient revealed how managerial efficiency-mix in resource allocation, among the experienced farmers enhanced their yield level. Therefore, the marginal and elasticity implications of an addition one year experience will increase farmers yield by 0.008 and $1.01 \%$ respectively. The positive sign and significant of the distance from house to market coefficient showed that high farm efficiency $v i z$. adequate concentration on farm activity other than non-farm and off-farm activities in the commercial centers among the farmers that have their abodes far apart from the market centers enhanced their yield. Therefore, the marginal and elasticity implications of a unit increase from a farmer's house to market by one kilometer will increase his/her yield by 0.005 and $0.27 \%$ respectively. The positive sign and significant of the co-operative coefficient indicated that pecuniary advantages viz. economies of scale among farmers that belonged to co-operative association enhanced their yield level. Thus, the marginal and elasticity implications of a farmer being a co-operative member will makes his/her yield to be higher than that of his counterpart farmer that didn't belong to co-operative association by 0.14 and $1,38 \%$ respectively.

However, explanatory variables viz. risk index, age, gender, educational level, mode of land acquisition and distance from home to farm were non-significant, but their signs convey empirical 
information. The positive sign of the risk index coefficient implied that farmers that have positive attitudes towards risk have high yield level. The negative sign of the age coefficient indicated that low labour productivity that owed to decline in labour efficiency among aged farmers plummeted yield. The positive sign of gender coefficient showed that access to and control over productive resources enhanced men farmers yield when compared to their women counterparts. The positive sign of educational level showed how innovation reception and search for market information among the literate farmers enhanced their yield.

Table 4: Determinants of yield among the rice farmers

\begin{tabular}{|l|l|l|l|l|}
\hline Variable & Coefficient & t-stat & Elasticity & VIF \\
\hline Intercept & $6.8405(0.1949)$ & $35.09^{* * *}$ & - & - \\
\hline Risk index & $0.0182(0.0697)$ & $0.262^{\mathrm{NS}}$ & 0.0000128 & 1.180 \\
\hline Age & $-8.72 \mathrm{e}-5(0.0036)$ & $0.023^{\mathrm{NS}}$ & -0.0008648 & 1.597 \\
\hline Gender & $0.0215(0.0823)$ & $0.261^{\mathrm{NS}}$ & 0.0023155 & 1.038 \\
\hline Marital status & $0.2430(0.1008)$ & $2.410^{* *}$ & 0.0277027 & 1.334 \\
\hline Education & $0.0022(0.0065)$ & $0.348^{\mathrm{NS}}$ & 0.0026578 & 1.060 \\
\hline Household size & $-0.0532(0.0159)$ & $3.346^{* * *}$ & -0.0314524 & 1.734 \\
\hline Experience & $0.0081(0.0046)$ & $1.759^{*}$ & 0.0106941 & 1.065 \\
\hline Mode of land acquisition & $-0.0202(0.0727)$ & $0.278^{\mathrm{NS}}$ & -0.001824 & 1.026 \\
\hline Distance from home to farm & $0.0044(0.0099)$ & $0.449^{\mathrm{NS}}$ & 0.0026921 & 1.135 \\
\hline Distance from home to market & $0.0573(0.0083)$ & $6.913^{* * *}$ & 0.0432765 & 1.191 \\
\hline Co-operative org. & $0.1404(0.0722)$ & $1.943^{*}$ & 0.0138544 & 1.052 \\
\hline Chi ${ }^{2}$ & $95.81[0.000]^{* * *}$ & & \\
\hline Normality test & $3.22[0.199]^{\mathrm{NS}}$ & & & \\
\hline
\end{tabular}

Source: Field survey, 2020

Note: $* * * * * \&$ NS mean significant at $1,5,10 \%$ and non-significant respectively.

Values in ( ) and [ ] are standard error and probability value respectively.

\section{Impact of Gender and Risk on Farmers' Yield}

All the treatment effect estimators viz. regression adjustment, inverse-probability weights, nearest-neighbor matching and propensity score matching showed that gender differential has no impact on the yield of the farmers as evidenced by their respective average treatment effect (ATE) coefficients which were not different from zero at $10 \%$ degree of freedom (Table 5). Though nonsignificant, the ATE estimated coefficient of the regression adjustment been 163.08 , indicates that the average yield level of the men farmers is marginally higher than of the women farmers by $163.08 \mathrm{~kg}$ (7.87\%). Furthermore, within each stratum, there is gender equity in yield distribution as indicated by their respective average treatment effect on treated (ATET) coefficients of all the treatment effect estimators that are not within the acceptable margin of $10 \%$ degree of freedom.
The empirical evidences showed that the extent of risk behaviour-risk differential has no impact on the average yield level of the farmers as indicated by the respective ATE coefficients of all the treatment effect estimators that are outside the plausible margin of $10 \%$ probability level (Table 6). The possible explanation is that most of the farmers are resource poor, smallholders, cultivating thinly uneconomic holding; with an output that lagged behind a balanced marketable surplus. Therefore, it can be inferred that there is no significant difference between the average yield levels of farmers that are negatively and positively disposed to risk. In other word, disposition to risk, either positively or negatively, has no impact on the average yield level of farmers. In addition, the use of unimproved varieties affected the correlation of yield with the degree of risk intensity. Though non-significant, the ATE coefficient of the regression adjustment been 97.04, implies that the average yield of positive risk attitude farmers is slightly higher than that of the risk 
averse' farmers by $97.04 \mathrm{~kg}$ (4.82\%). Furthermore, except the ATET coefficient of inverse-probability weight, in each of the stratum- negative and positive risk attitudes, all the other treatment effect estimators revealed equal yield distribution among farmers with negative attitudes towards risk; likewise those with positive attitudes towards risk.

Table 5: Impact of gender on farmers' yield

\begin{tabular}{|c|c|c|c|c|}
\hline \multirow{2}{*}{ Items } & Coefficient & t-stat & Coefficient & t-stat \\
\hline & \multicolumn{2}{|c|}{ Regression adjustment } & \multicolumn{2}{|c|}{ Inverse-probability weight } \\
\hline ATE & $-163.08(279.40)$ & $0.58^{\mathrm{NS}}$ & $-293.70(400.82)$ & $0.73^{\mathrm{NS}}$ \\
\hline ATET (Men) & $246.80(252.01)$ & $0.98^{\mathrm{NS}}$ & $227.04(249.07)$ & $0.91^{\mathrm{NS}}$ \\
\hline ATET (Women) & $-143.58(293.81)$ & $0.49^{\mathrm{NS}}$ & $-309.44(447.25)$ & $0.69^{\mathrm{NS}}$ \\
\hline Men (mean) & $2072.49(277.75)$ & $7.46^{* * * *}$ & $2206.67(399.35)$ & $5.53 * * *$ \\
\hline \multirow[t]{2}{*}{ Women (mean) } & $1909.41(68.14)$ & $28.02 * * *$ & $1912.97(68.00)$ & $28.13 * * *$ \\
\hline & \multicolumn{2}{|c|}{ Nearest-neighbor matching } & \multicolumn{2}{|c|}{ Propensity-score matching } \\
\hline ATE & $-3.33(264.83)$ & $0.01^{\mathrm{NS}}$ & $-680.00(520.99)$ & $1.31^{\mathrm{NS}}$ \\
\hline ATET (Men) & $324.20(281.20)$ & $1.15^{\mathrm{NS}}$ & $302.05(202.24)$ & $1.49^{\mathrm{NS}}$ \\
\hline ATET (Women) & $71.38(274.87)$ & $0.26^{\mathrm{NS}}$ & $-768.01(600.47)$ & $1.28^{\mathrm{NS}}$ \\
\hline
\end{tabular}

Source: Field survey, 2020

Note: ATE and ATET mean Average treatment effect and Average treatment effect on treated, respectively.

Note: $* * * * * *$ \&S means significant at $1 \%, 5 \%, 10 \% \&$ Non-significant, respectively.

Figure in ( ) is standard error

Table 6: Impact of risk attitudes on farmers' yield

\begin{tabular}{|l|l|l|l|l|}
\hline \multirow{2}{*}{ Items } & Coefficient & t-stat & Coefficient & t-stat \\
\cline { 2 - 5 } & \multicolumn{2}{|l|}{ Regression adjustment } & \multicolumn{2}{l|}{ Inverse-probability weight } \\
\hline ATE & $97.03(164.23)$ & 0.59 & $65.35(155.13)$ & 0.42 \\
\hline ATET (PRA) & $98.15(160.56)$ & 0.61 & $130.13(161.14)$ & 0.81 \\
\hline ATET (NRA) & $-96.32(175.51)$ & 0.55 & $-25.43(163.71)$ & 0.16 \\
\hline PRA (mean) & $2014.89(148.09)$ & 13.61 & $1970.10(138.31)$ & 14.24 \\
\hline NRA (mean) & $1917.86(80.01)$ & 23.97 & $1904.75(77.59)$ & 24.55 \\
\hline & Nearest-neighbor matching & \multicolumn{2}{|l|}{ Propensity-score matching } \\
\hline ATE & $172.05(157.38)$ & 1.09 & $220.54(246.86)$ & 0.89 \\
\hline ATET (PRA) & $327.29(180.89)$ & 1.81 & $273.08(185.34)$ & 1.47 \\
\hline ATET (NRA) & $-73.26(179.39)$ & 0.41 & $-187.11(332.48)$ & 0.56 \\
\hline
\end{tabular}

Source: Field survey, 2020

Note: ATE and ATET mean Average treatment effect and Average treatment effect on treated, respectively.

Note: $* * * * * *$ \&S means significant at $1 \%, 5 \%, 10 \%$ \& Non-significant, respectively.

Figure in ( ) is standard error; PRA = Positive risk attitude; NRA = Negative risk attitude. 


\section{Effects of Gender and Risk Discriminations on Yield Gap}

A cursory review of the gender-wise results showed endowment factors viz. risk index, marital status, educational level, household size, experience and distance from house to market contributed favourably to women farmers' yield; while age, mode of land acquisition, distance from house to farm and co-operative membership contributed favourably to the yield of the men farmers (Table 7). The difference between the coefficients of the predictor variables vis-à-vis simultaneous equationbetween the men and women yield equations; were the major factors that contributed to the yield gap between the two genders. Furthermore, the empirical evidences showed that $72.09 \%$ of the yield gap was largely caused by discrimination effect called gender while $27.91 \%$ owed to endowment effect called characteristic factors. With an average yield of 1883.30 and $2268.40 \mathrm{~kg}$ for women and men farmers respectively, the yield gap is $385.10 \mathrm{~kg}$. Out of the yield gap of $385 \mathrm{~kg}$, the difference due to superior endowment of the men gender accounted for $107.46 \mathrm{~kg}$ while gender discrimination viz. access to and control over productive resources, and gender stereotype accounted for $277.64 \mathrm{~kg}$. Thus, the consequence of gender discrimination made women farmers to lost $277.64 \mathrm{~kg}$ of rice output per hectare. Besides, the discrimination value represents $14.72 \%$ of the actual average yield of women gender. Given the technology at the disposal of the women farmers, without gender discrimination, their actual average yield should be $2160.94 \mathrm{~kg}$. The estimated yield gap is $-18.61 \%$ (i.e. $\ln \bar{Y}_{W}-\ln \bar{Y}_{M}=-0.1861$ ), the resource endowment effect is $19.09 \%$ [i.e. $\left(\bar{X}_{W}-\right.$ $\left.\left.\bar{X}_{M}\right) \hat{\beta}_{W}=0.1909\right]$, and the discrimination effect is $49.32 \%$ [i.e. $\left(\hat{\beta}_{W}-\hat{\beta}_{M}\right) \bar{X}_{M}=0.4932$ ] (Figure 1). The positive sign of the endowment effect coefficient implies that relative to men farmers, women farmers on the average have more characteristics that are associated with high productivity.

On the other hand, the risk-wise results showed age, gender, educational level, household size, mode of land acquisition and distance from house to farm to be the endowed factors that contributed favourably to the yield of farmers with negative disposition towards risk (Table 8). While endowed factors viz. marital status, experience, distance from house to market and co-operative membership contributed favourably to the yield of farmers with positive attitude towards risk. Thus, the predictor coefficient differentials between the farmers with negative attitude towards risk and those with positive disposition towards risk from the twoyield equation were the major factors that contributed to yield gap. Of the yield gap, discrimination effect called risk attitudesopportunities accounted for $86.47 \%$ of the yield gap while endowment effect called idiosyncratic factors accounted for $13.53 \%$ of the yield gap. With an average yield of 1865.88 and $2093.01 \mathrm{~kg}$ respectively for the risk averter and non-risk averter farmers, the yield gap is $227.12 \mathrm{~kg}$. Out of the yield gap of $227.12 \mathrm{~kg}$, the difference due to the superior endowment of the farmers with positive disposition towards risk accounted for $30.72 \mathrm{~kg}$ while discrimination in risk attitudes accounted for $196.40 \mathrm{~kg}$. Thus, due to risk attitudinal discrimination, the risk averter farmers lost $196.40 \mathrm{~kg}$ of rice output per hectare. The value of the discrimination represents $10.53 \%$ of the actual average yield of risk averter farmers. Given the technology at the disposal of the risk averter farmers, without risk behaviour discrimination, their actual average rice yield should be $2062.28 \mathrm{~kg}$. The estimated yield gap is $-11.49 \%$ (i.e. $\ln \bar{Y}_{R N}-\ln \bar{Y}_{R P}=$ -0.1149 ), the resource endowment effect is $-8.4 \%$ [i.e. $\left.\left(\bar{X}_{R N}-\bar{X}_{R P}\right) \hat{\beta}_{R N}=-0.084\right], \quad$ and the discrimination effect is $-53.58 \%$ [i.e. $\left(\hat{\beta}_{R N}-\right.$ $\left.\left.\hat{\beta}_{R P}\right) \bar{X}_{R P}=-0.5358\right]$ (Figure 1). The negative sign of endowment effect coefficient means that relative to the risk averter farmers, on the average, farmers with positive attitudes towards risk have more characteristics that are associated with high yield.

Generally, it can be inferred be inferred that yield gap was entirely due to gender and risk attitudinal discriminations in the studied area.

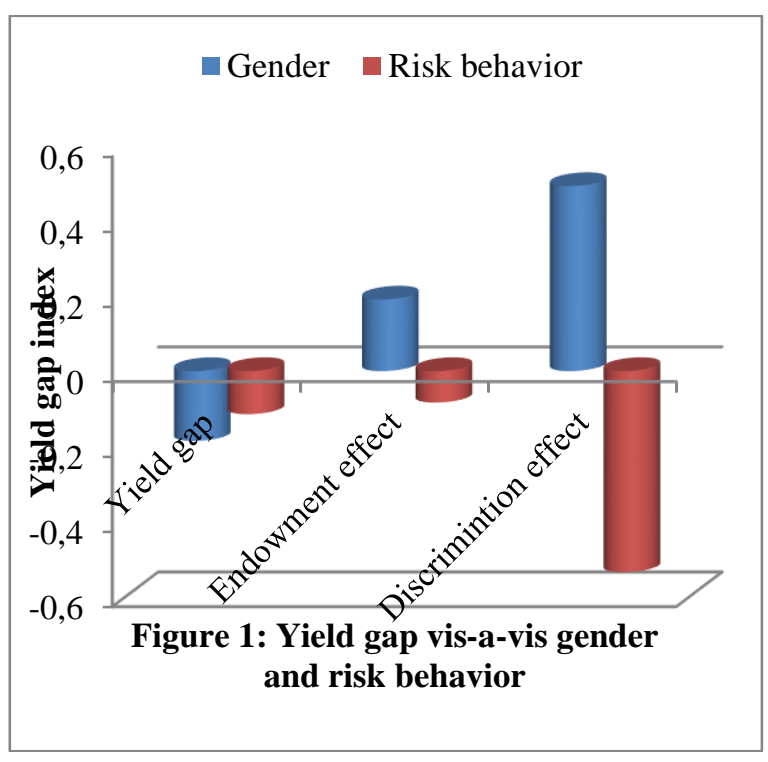


Table 7: Productivity gap by gender

\begin{tabular}{|c|c|c|c|c|c|c|}
\hline Items & Female & Male & $\bar{X}_{F}$ & $\bar{X}_{M}$ & $\boldsymbol{\beta}_{F}\left(\overline{\boldsymbol{X}}_{F}-\overline{\boldsymbol{X}}_{M}\right)$ & $\overline{\boldsymbol{X}}_{M}\left(\boldsymbol{\beta}_{F}-\boldsymbol{\beta}_{M}\right)$ \\
\hline Intercept & 6.350679 & 6.961687 & & & & -0.61101 \\
\hline Risk index & -0.13943 & 0.075062 & -0.06188 & 0.014409 & 0.010637 & -0.00309 \\
\hline Age & 0.001735 & 0.00217 & 41.074 & 41.592 & -0.0009 & -0.01808 \\
\hline Marital status & 0.463365 & 0.183042 & 0.89706 & 0.83219 & 0.030058 & 0.233282 \\
\hline Education & 0.019113 & -0.00122 & 8.5882 & 7.9658 & 0.011896 & 0.161957 \\
\hline Household size & -0.1405 & -0.05054 & 3.9118 & 4.4178 & 0.071093 & -0.39741 \\
\hline Experience & 0.020387 & 0.003961 & 10.221 & 9.5514 & 0.013651 & 0.156892 \\
\hline Mode of land acquisition & -0.16079 & -0.01298 & 0.76471 & 0.72945 & -0.00567 & -0.10782 \\
\hline Distance from home to farm & 0.033492 & -0.00038 & 4.1029 & 4.399 & -0.00992 & 0.148988 \\
\hline Distance from home to market & 0.084456 & 0.049826 & 6.3971 & 5.5137 & 0.074608 & 0.190939 \\
\hline Co-operative organization & 0.273658 & 0.097219 & 0.70588 & 0.7226 & -0.00458 & 0.127494 \\
\hline Average yield & 1883.3 & 2268.4 & & & & \\
\hline Yield gap & & -385.1 & & & & \\
\hline Endowment effect & & & & & $\mathbf{0 . 1 9 0 8 8 3}$ & \\
\hline Discrimination effect & & & & & & 0.493151 \\
\hline Overall effect & & & & & & 0.684034 \\
\hline \% from overall effect & & & & & 27.90545 & 72.09455 \\
\hline Contribution to Gap & & & & & -107.464 & -277.636 \\
\hline Without Discrimination & & & & & 2160.936 & 2160.936 \\
\hline$\%$ of Discrimination in yield & & & & & & 14.742 \\
\hline
\end{tabular}

Source: Field survey, 2020 
Table 8: Productivity gap by risk attitudes

\begin{tabular}{|c|c|c|c|c|c|c|}
\hline Items & NRA & PRA & $\bar{X}_{N R A}$ & $\bar{X}_{P R A}$ & $\boldsymbol{\beta}_{N}\left(\overline{\boldsymbol{X}}_{N}-\overline{\boldsymbol{X}}_{P}\right)$ & $\overline{\boldsymbol{X}}_{P}\left(\boldsymbol{\beta}_{N}-\boldsymbol{\beta}_{P}\right)$ \\
\hline Intercept & 7.004293 & 6.464656 & & & & 0.539637 \\
\hline Age & -0.00023 & 0.001851 & 41.43182 & 41.56835 & $3.17 \mathrm{E}-05$ & -0.08656 \\
\hline Gender & -0.01973 & 0.161325 & 0.804545 & 0.820144 & 0.000308 & -0.14849 \\
\hline Marital status & 0.306355 & 0.081974 & 0.831818 & 0.863309 & -0.00965 & 0.19371 \\
\hline Education & 0.000742 & 0.012034 & 8.254545 & 7.856115 & 0.000296 & -0.08871 \\
\hline Household size & -0.06312 & -0.03261 & 4.113636 & 4.647482 & 0.033695 & -0.14179 \\
\hline Experience & 0.005933 & 0.012349 & 9.345455 & 10.1295 & -0.00465 & -0.06499 \\
\hline Mode of land acquisition & -0.09746 & 0.132064 & 0.731818 & 0.741007 & 0.000896 & -0.17008 \\
\hline Distance from home to farm & -0.00942 & 0.015662 & 4.043182 & 4.805755 & 0.007187 & -0.12056 \\
\hline Distance from home to market & 0.061149 & 0.054313 & 5.072727 & 6.669065 & -0.09761 & 0.045594 \\
\hline Co-operative organization & 0.133885 & 0.075076 & 0.677273 & 0.784173 & -0.01431 & 0.046116 \\
\hline Average yield & 1865.882 & 2093.005 & & & & \\
\hline Yield gap & & -227.123 & & & & \\
\hline Endowment effect & & & & & -0.08381 & \\
\hline Discrimination effect & & & & & & -0.53578 \\
\hline Overall effect & & & & & & -0.61959 \\
\hline$\%$ from overall effect & & & & & 13.52729 & 86.47271 \\
\hline Contribution to Gap & & & & & -30.7236 & -196.399 \\
\hline Without Discrimination & & & & & 2062.281 & 2062.281 \\
\hline \% of Discrimination in yield & & & & & & 10.5258 \\
\hline
\end{tabular}

Source: Field survey, 2020

Note: NRA= Negative risk attitude; PRA= Positive risk attitude 


\section{CONCLUSION AND RECOMMENDATIONS}

Based on the findings it can be concluded that most of the farmers have negative attitudes towards risk and it owes largely to poor capital resource base. Besides, women farmers were found to be more averse to risk than their men counterparts; and it owes to gender discrimination viz. culture and religion barriers that hinder women farmers' access to and control over productive resources. Further, neither gender differential nor risk behaviour differential has impact on the average yield of the farmers. However, it was established that yield gap was largely due to gender and risk attitudinal discriminations. Therefore, based on the foregoing, the study advised the farmers, especially women folk, to utilize social capital pool so as to have access to productive resources viz. pecuniary advantages. By so doing, it will break the chain of gender discrimination and stereotype. In addition, the policymakers should create enable agricultural environment for women farmers viz gender budget mainstreaming, thus reducing women farmers' vulnerability to vicious cycle of poverty.

\section{REFERENCES}

Alderman, H. (2008). Managing risk to increase efficiency and reduce poverty. World Development Report 2008. Washington, DC:World Bank.

Amber, P., Behrman, J.A. and Quisumbing, A.R. (2014). A review of empirical evidence on gender differences in nonland agricultural inputs, technology, and services in developing countries. Gender in Agriculture. Pp 145-186.

Averett, S.L., Laura, M.A. and Saul, D.H. (2018). The Oxford Handbook of Women and the Economy. Oxford University Press.

Blinder, A.S. (1973). Wage discrimination: reduced form and structural estimates. Journal of Human Resources, 8(4):436-455.

Charness, G.., Uri, G. and Alex, I.(2013).Experimental methods: eliciting risk preferences. Journal of Economic Behavior and Organization, 87:43-51.

Cotula, L. (2006). Gender and law: women's rights in agriculture. Food and Agriculture Organization.
Di Falco, S. and Chavas, J-P. (2009). On crop biodiversity, risk exposure, and food security in the highlands of Ethiopia. American Journal of Agricultural Economics, 91(3):599-611

Digital Green (no date). Digital Green. Accessed from www.digitalgreen.org.

Dohmen, T., Armin, F., David, H. and Uwe, S. (2012). The intergenerational transmission of risk and trust attitudes. The Review of Economic Studies, 79(2):645-677.

Dohmen, T., Armin, F., David, H., Uwe, S., Jürgen, S. and Gert, G.W. (2011). Individual risk attitudes: measurement, determinants, and behavioral consequences. Journal of the European Economic Association, 9(3):522550 .

Kaiser, H.F. (1974). An index of factorial simplicity. Psychometrika, 39 (1), 31-36.

Ligon, E. and Elisabeth, S. (2008). Estimating the effects of aggregate agricultural growth on the distribution of expenditures.

Lokshin, M. and Sajaia, Z.(2011).Impact of interventions on discrete outcomes: Maximum likelihood estimation of the binary choice models with binary endogenous regressors. The Stata Journal, 11(3): 11-21.

Marwa, B. (2014). Estimation of gender wage differentials in Egypt using Oaxaca Decomposition technique. Paper presented at the $34^{\text {th }}$ annual MEEA meeting in conjunction with the Allied Social Science Association (ASSA), Philadelphia, January 36, 2014, Pp. 1-26

Oaxaca, R. (1973). Male-female wage differentials in urban labor markets. International Economic Review, 9:693-709.

Olayemi, I.K., Idris, B., Ejima, I.A.A., Adeniyi, K., Ukubuiwe, A.C. and Isah, B. (2014). The climate of north-central Nigeria and potential influence on mosquito (Diptera culicidae) vectorial capacity for disease transmission. Global Journal of Multidisciplinary and Applied Sciences, 2(2):26-31

Revathy, N., Thilagavathi, M. and Surendran, A. (2020). A comparative analysis of ruralurban migrants and non-migrants in the selected region of Tamil Nadu, India. Economic Affairs, 65(1): 23-30. 
Sadiq, M.S., Singh, I.P. and Ahmad, M.M. (2020a). Rice yield differentials between IFAD participating and non-participating farmers in Nigeria's Niger State. Economic Affairs, 65(4): 01-15

Sadiq, M.S., Singh, I.P., Ahmad, M.M. and Kumari, V.(2020b). Effect of gender on income gap among fish farmers in Nigeria's Kogi State. Atatürk Üniversitesi Kadın Araştırmaları Dergisi (Atatürk University Journal of Woman's Studies), 2(2): 27-45
Sepahvand, M.H. (2019). Agricultural productivity in Burkina Faso: The role of gender and risk attitudes. Working Paper 3, Department of Economics, Uppsala University, Sweden.

Tobin, J. (1958). Estimation of relationship for limited dependent variables. Econometrica, 26: $26-36$

Wang, A., Nianogo, R.A. and Arah, O.A. (2017).Gcomputation of average treatment effects on the treated and the untreated. BMC Medical Research Methodology, 17(3): 1-5. 